\title{
White-Footed Ant, Technomyrmex albipes (Fr. Smith) (Insecta: Hymenoptera: Formicidae: Dolichoderinae) $)^{1}$
}

\section{J. Warner, R. H. Scheffrahn and B. Cabrera ${ }^{2}$ \\ Introduction}

The white-footed ant, Technomyrmex albipes (Fr. Smith) has been making news in Florida over the last few years as a pest ant of major importance. Pest control companies, the media and homeowners continually consult universities and government agencies for information on how to control this nuisance ant. This report provides recent information (August 2002) on the distribution and habits of the white-footed ant (WFA) in Florida and the research being conducted on improved control practices.

\section{Distribution}

WFA was first collected in Florida at a nursery in Homestead in 1986. Mark Deyrup (Deyrup 1991) collected, and later identified WFA in Miami. As of July 2002, WFA have been collected in Brevard, Broward, Collier, Dade, Hendry, Lee, Martin, Monroe, Orange, Palm Beach, Polk, St. Lucie, Sarasota, and Seminole Counties, and more recently in Hillsborough and Pinellas Counties (Scheffrahn, unpublished data). By 2004, suspected infestations in Indian River and Charlotte counties were confirmed. In addition, infestations were confirmed in Alachua
(April), Lake (March), Pasco and Volusia (April) counties.

Small infestations of WFA are now known in South Carolina and in Louisiana (New Orleans), most likely coming from Florida.

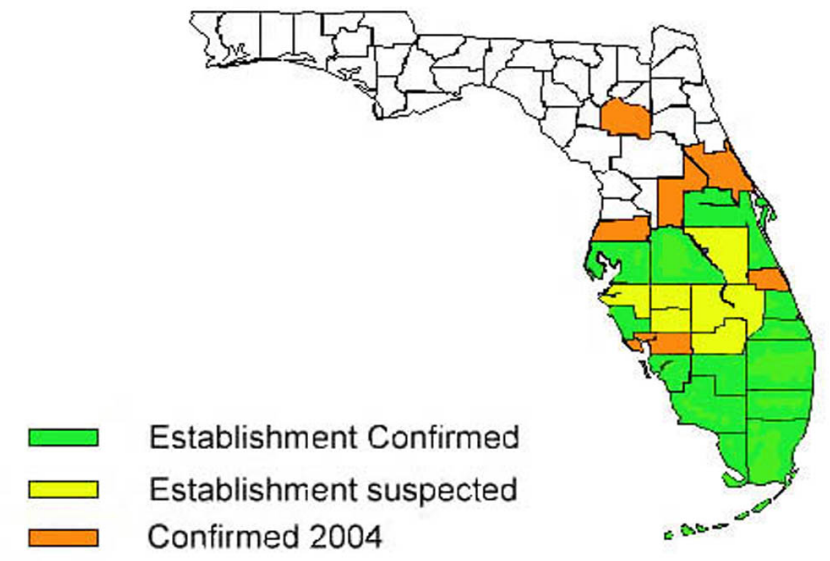

Figure 1. White-footed ant infestations in Florida. Credits: R.H. Scheffrahn, University of Florida

The WFA will likely saturate urban and suburban habitats in central and south Florida in the next few years, and possibly spread throughout the State. One of the most important means of distribution appears

1. This document is EENY-273, one of a series of Featured Creatures from the Entomology and Nematology Department, Florida Cooperative Extension Service, Institute of Food and Agricultural Sciences, University of Florida. Published: August 2002. This document is also available on Featured Creatures Website at http://creatures.ifas.ufl.edu. Please visit the EDIS Website at http://edis.ifas.ufl.edu.

2. J. Warner, R. H. Scheffrahn and B. Cabrera, Entomology and Nematology Department, Ft. Lauderdale Research and Education Center, Institute of Food and Agricultural Sciences, University of Florida, Ft. Lauderdale, FL.

The Institute of Food and Agricultural Sciences (IFAS) is an Equal Employment Opportunity - Affirmative Action Employer authorized to provide research, educational information and other services only to individuals and institutions that function without regard to race, creed, color, religion, age, disability, sex, sexual orientation, marital status, national origin, political opinions or affiliations. For information on obtaining other extension publications, contact your county Cooperative Extension Service office. Florida Cooperative Extension Service / Institute of Food and Agricultural Sciences / University of Florida / Larry R. Arrington, Interim Dean 
to be via transportation of infested residential landscaping plants and materials (Warner, unpublished data).

The WFA, was described from Sulawesi, Indonesia (Smith 1861) and has spread to Japan, Australia, New Zealand, Polynesia, Africa, Hawaii (first recorded in 1911 by Swezey 1915), and most recently the British West Indies (October 2003). It is impossible to pinpoint its mode or place of entry into Florida but introduction of the WFA was most likely accidental.

\section{Pest Status}

The WFA does not bite or sting, nor has it been reported to cause any structural damage. Colony population estimates vary from 8,000 to 3 million individuals (Tsuji and Yamauchi 1994). WFAs are considered by homeowners to be a nuisance pest because they are frequently observed foraging in kitchens, bathrooms, and the exterior of buildings.

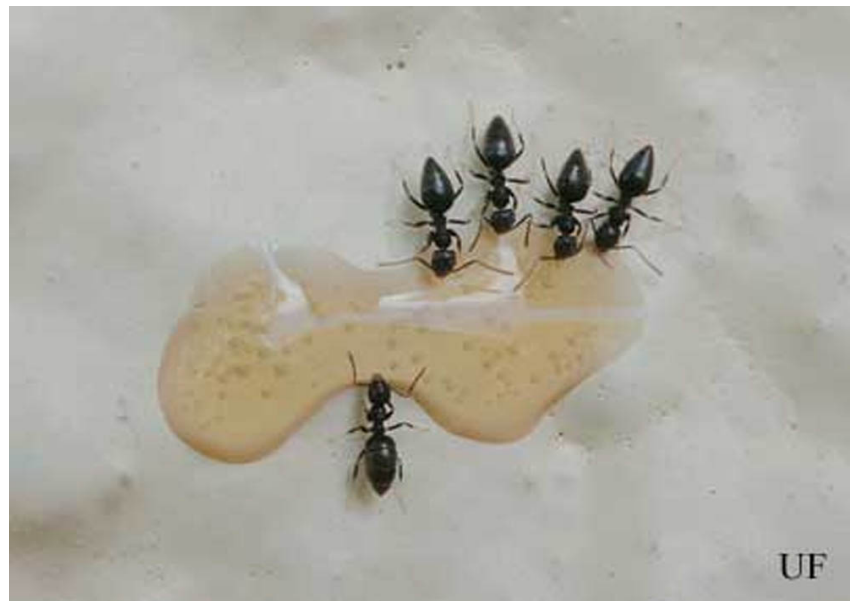

Figure 2. White-footed ants, Technomyrmex albipes (Fr. Smith), feeding on soda droplet. Credits: R.H. Scheffrahn, University of Florida

WFA feed on plant nectars and honeydew, which is a sweet substance produced by many sap-sucking insects such as aphids, mealybugs, and scales. WFA are known to protect honeydew producers, which has caused problems in agricultural production in some areas of the world. In Sri Lanka WFA are known to play a major role in spreading the pineapple wilt disease due to their tending of the pink mealybug, Dysmicoccus brevis (Cockerell) (Sulaiman 1997). On the other hand, Way \& Cammel (1989) report WFAs help control a pest of coconut in Sri Lanka, the coconut caterpillar, Opisina arenosaella Walker, by feeding on the caterpillars' eggs. In South African citrus orchards, WFA caused localized outbreaks of red scale Aonidiella aurantii (Maskell) (Samways et al. 1982). Charles (1993), reports WFA tending mealybugs Pseudococcus longispinus (T.-T) in citrus and persimmon orchards.

\section{Description}

The WFA is a medium small (2.5-3 mm long), black to brownish-black ant with yellowish-white tarsi (feet) and a one-segmented waist. A member of the subfamily Dolichoderinae, WFA have five abdominal segments, 12-segmented antennae, few erect hairs, and no sting.

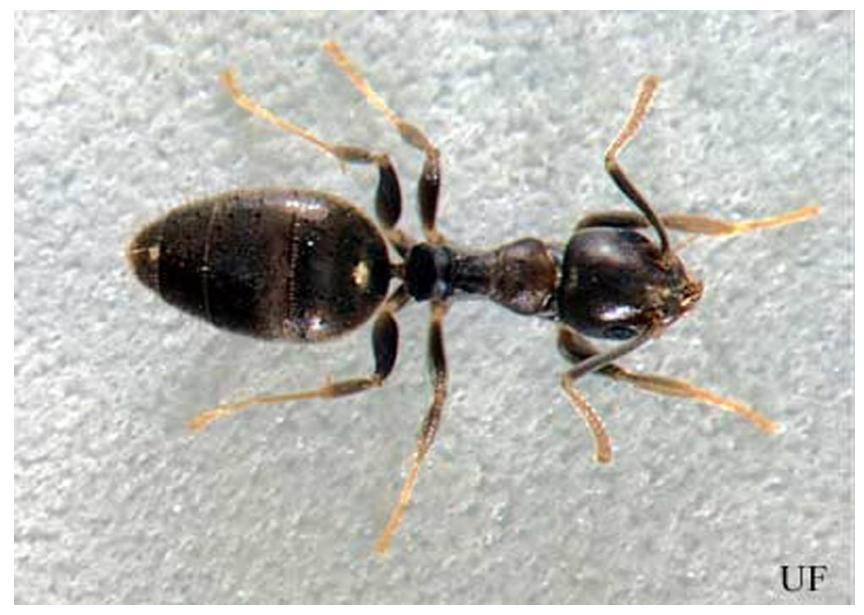

Figure 3. Worker of the white-footed ant, Technomyrmex albipes (Fr. Smith). Credits: R.H. Scheffrahn, University of Florida

The WFA looks similar to the Argentine ant, Linepithema humile (Mayr). However, the petiole of the Argentine ant has a vertical projection that is lacking on the WFA. In south Florida, WFAs are frequently confused with Paratrechina bourbonica (Forel), one of the "crazy ants." Paratrechina bourbonica is slightly larger than the WFA, is faster-moving, has more hair, and emits a slight fruity odor when crushed.

\section{Life Cycle}

Perhaps the key to the WFA's evolutionary success is its ability to reproduce in large numbers, especially considering that it doesn't have the obvious defensive capabilities of many other ants such as a venomous sting, chemical sprays, or 
soldiers with strong, biting mandibles. Nearly half of the entire WFA colony is composed of fertile, reproductive females called intercastes that are usually inseminated by wingless males (Yamauchi et al. 1991). Although dealate queens are rare, winged males, which are short-lived, and winged females are released from the colony yearly, usually between July and August in South Florida. These forms copulate during a nuptial flight and found new colonies. Brood (eggs, larvae, and pupae) begin to develop under the care of the founding queen and the nest population increases. Foragers bring back food resources that they share with nestmates through the production of non-viable trophic eggs. The dealate queen is eventually replaced by the intercastes, which can form further new colonies by a process called budding in which the intercastes leave the old colony with other nestmates and brood to establish a new nest site.

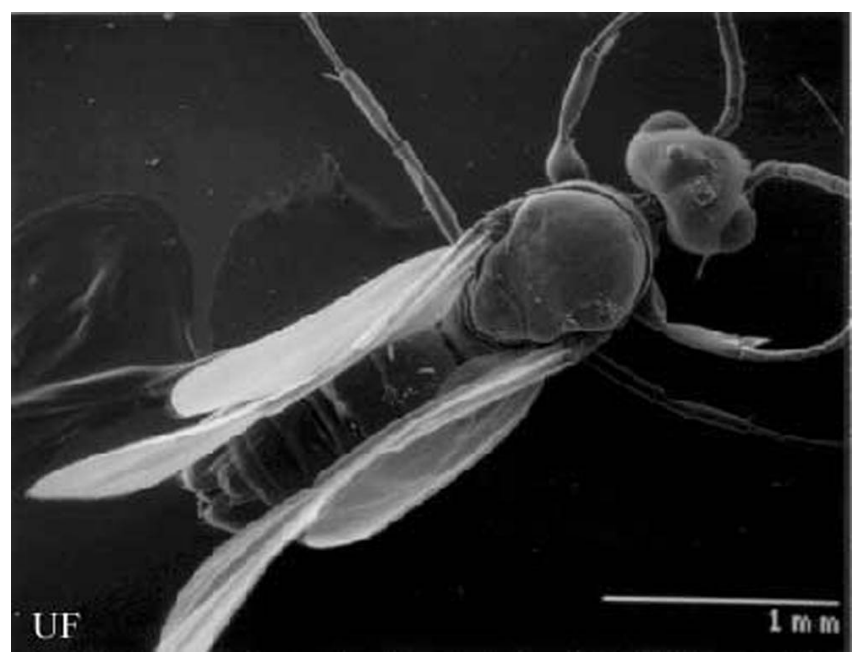

Figure 4. Scanning Electron Micrograph of a whitefooted ant male alate, Technomyrmex albipes (Fr. Smith). Credits: J. Warner and R.H. Scheffrahn, University of Florida

\section{Foraging and Feeding}

Although WFAs are strongly attracted to sweet foods they will also feed on dead insects and other protein. WFAs are commonly found foraging along branches and trunks of trees and shrubs that have nectars and/or sap-sucking insects that produce honeydew. WFAs send many foragers from their nests to search for new food resources. Nestmates are recruited to resources by foragers who lay trail pheromones. Often the same trails are observed between a nest and resource for months at a time. In and on structures, foragers tend to follow lines, such as an edge of an exterior wall panel, which eventually leads to some small opening to the interior, where foragers that enter become more noticeable to occupants. Frequently, WFA find their way inside wall voids where they follow electrical cables and emerge into various rooms, especially kitchens and bathrooms, where liquid and solid foods can be encountered resulting in heavy trailing activity.

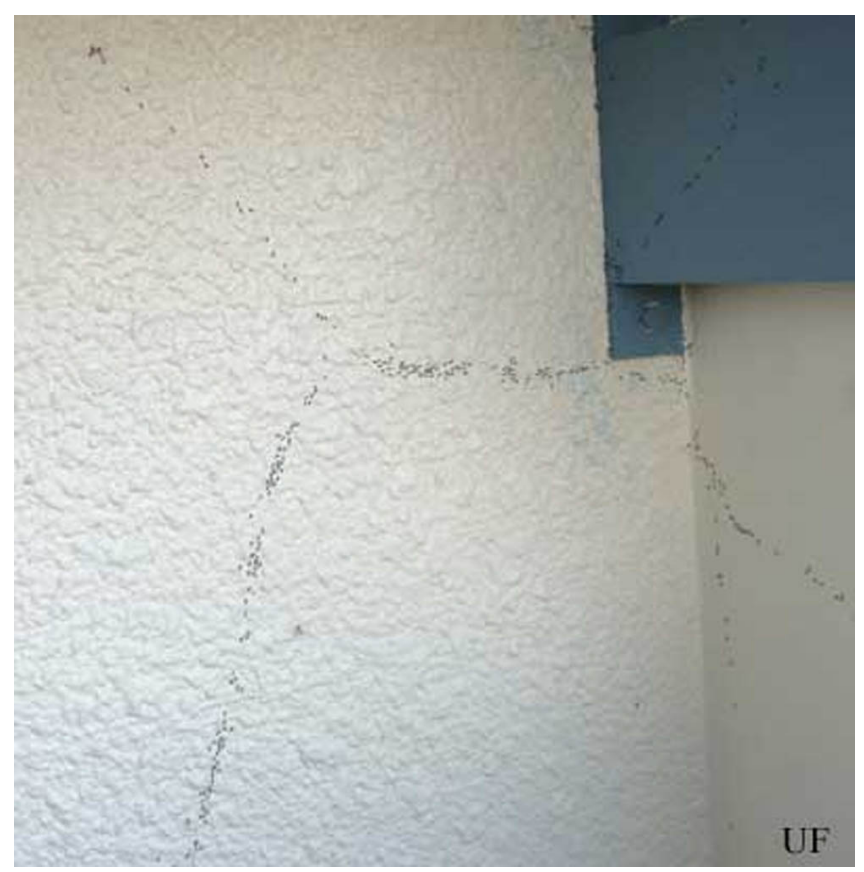

Figure 5. White-footed ants, Technomyrmex albipes (Fr. Smith), trailing on a building. Credits: R.H. Scheffrahn, University of Florida

A video of white-footed ants, Technomyrmex albipes (Fr. Smith), trailing on a building, by J.Warner, University of Florida.

\section{Nest Sites}

The WFA nests at or above ground level in numerous locations within the landscape and home. Nests are frequently found in trees and bushes, tree holes, under palm fronds and old leaf boots, under leaves on trees, in loose mulch, under debris, in leaf-litter (both on the ground as well as in rain gutters), wall voids, and attics. Nests tend to be found outside of structures more than inside. Preferred nest sites provide proximity to moisture and food sources, and protection from predators and environmental extremes. Numerous nests can be said to constitute a colony, but since all neighboring colonies seems to be 
interconnected, there is probably no way to delineate the limits of a single colony.

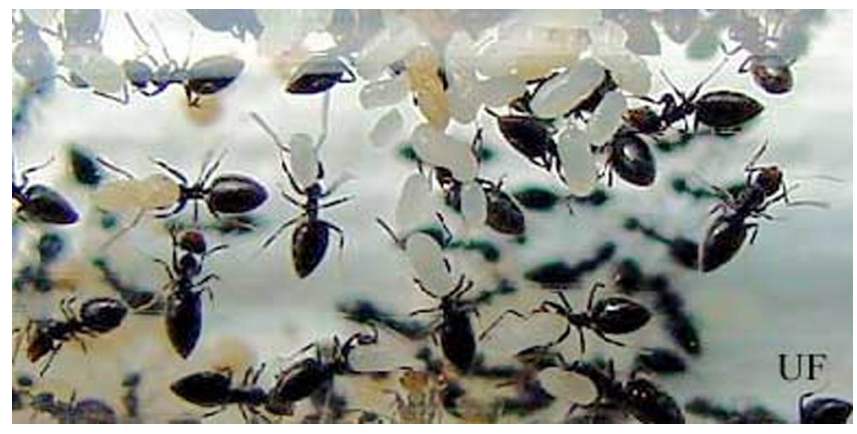

Figure 6. White-footed ants, Technomyrmex albipes (Fr. Smith), tending brood. Credits: J. Warner, University of Florida

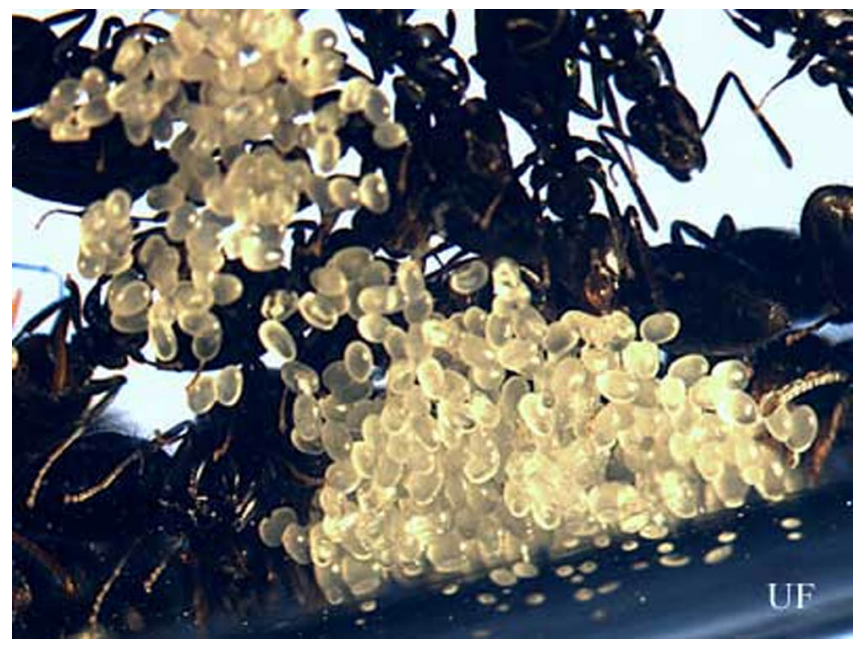

Figure 7. White-footed ants, Technomyrmex albipes (Fr. Smith), tending eggs. Credits: J. Warner, University of Florida

\section{Management}

WFA is an extremely difficult pest to control due to the large size of its colonies, but control can be achieved. Baits are effective for many sweet-feeding ant species. Laboratory tests at the University of Florida Research and Education Center in Fort Lauderdale have shown baits to be the only effective management method to date for WFA control. No surface or residual treatments with liquid insecticides have yet been found to be effective for controlling these ants. Management has only been accomplished by treating infested homes exclusively with baits containing borates. It is critical that all populations of WFA on the property being treated are identified so that baits can be made available to each population. Since liquid baits tend to slowly dry out, it is important that fresh baits are always available until the target population has been controlled. Although bait toxicants may not be orally transferred between workers, they can still kill enough workers to cause death of brood by starvation. In addition, it is also thought that very slow acting bait toxicants may, with time, end up in the trophic eggs. Residual and systemic sprays to vegetation surrounding structures can also help by eliminating honeydew producing insects.

WFA trails meandering up the sides of houses can often be seen entering soffit vents that lead into attics. Because attics usually do not have food sources for ants, infestations can frequently be treated by placing liquid baits along trails on the exterior of the house. This will cause ants nesting in the attic to emerge to feed on the baits. Treating the attic with an insecticidal dust or spray might also be advisable in extreme infestations. Always follow label directions when using an insecticide.

A key aspect of WFA control involves trimming trees and shrubs surrounding the structure to stop ants from "bridging" (trailing from the vegetation onto the structure). The best policy is to not have any vegetation touching exterior walls. Large trees infested with WFA which overhang the structure should also be trimmed back to stop "leaf nests" from falling onto roofs which can cause reinfestation of the building. Placing liquid baits at the base of these trees or along branches can also be helpful. Ant trails coming from neighboring properties via adjoining vegetation, fences, or across lawns, must also be treated.

Vegetation favored by WFA in south Florida includes: nearly all palms, especially coconut, sable, or queen, most fruit trees, large ficus trees, gardenia, hibiscus, ixora, many plants having showy flowers with sweet nectars and most plants which are infested with aphids, scales, mealybugs or other sap-sucking insects.

In most cases it is advisable to hire a professional pest control company to treat WFA infestations. 


\section{Selected References}

Charles JG. 1993. A survey of mealybugs and their natural enemies in horticultural crops in North Island, New Zealand, with implications for biological control. Biocontrol Science and Technology 3: 405-418.

Deyrup M. 1991. Technomyrmex albipes, a new exotic ant in Florida (Hymenoptera: Formicidae). Florida Entomologist 74: 147-148.

Samways MJ, Nel M, Prins AJ. 1982. Ants (Hymenoptera: Formicidae) foraging in citrus trees and attending honeydew-producing Homoptera. Phytophylactica 14: 155-157.

Smith F. 1861. Catalogue of hymenopterous insects collected by Mr. A.R. Wallace in the Islands of Ceram, Celebes, Ternate, and Gilolo. Journal of the Proceedings of the Linnean Society, Zoology 6: $36-48$.

Sulaiman SFM. 1997. Impact of weed management on ant density and fruit yield in the control of pineapple wilt disease. Acta horticulturae 425: 475-484.

Tsuji K, Yamauchi K. 1994. Colony level sex allocation in a polygynous and polydomous ant. Behavioral Ecology and Sociobology 34: 157-167.

Way MJ. 1989. Ants (Hymenoptera:

Formicidae) as egg predators of coconut pests, especially in relation to biological control of the coconut caterpillar, Opisina arenosella Walker (Lepidoptera: Xyloryctidae), in Sri Lanka. Bulletin of Entomological Research 79: 219-233.

Yamauchi KT, Furukawa T, Kinomura K, Takamine H, Tsuji K. 1991. Secondary polygyny by inbred wingless sexuals in the dolichoderine ant Technomyrmex albipes. Behavioral Ecology and Sociobology 29: 313- 319. 